Article

\title{
European Parliament Elections of May 2014: Driven by National Politics or EU Policy Making?
}

\author{
Hermann Schmitt ${ }^{1,2}$ and Illke Toygür ${ }^{3,4, *}$ \\ ${ }^{1}$ Department of Politics, University of Manchester, Manchester, M13 9PL, UK \\ ${ }^{2}$ MZES, University of Mannheim, 68131 Mannheim, Germany; E-Mail: hermann.schmitt@mzes.uni-mannheim.de \\ ${ }^{3}$ Department of Political Science and International Relations, Autonomous University of Madrid, 28049 Madrid, Spain; \\ E-Mail: ilke.toygur@uam.es \\ ${ }^{4}$ Istanbul Policy Center, Sabanci University, 34420 Istanbul, Turkey \\ * Corresponding author
}

Submitted: 5 October 2015 | Accepted: 18 January 2016 | Published: 29 February 2016

\begin{abstract}
The 2014 European Parliament (EP) elections took place in a very particular environment. Economic crisis, bailout packages, and austerity measures were central on the agenda in many Southern countries while open borders and intra-EU migration gained high salience elsewhere in the Union. A strong decline of political trust in European and national institutions was alarming. At the same time, the nomination and campaigning of "Spitzenkandidaten", lead candidates of EP political groups for European Commission (EC) presidency, was meant to establish a new linkage between European Parliament elections and the (s)election of the president of the Commission. All of this might have changed the very nature of EP elections as second-order national elections. In this paper, we try to shed light on this by analysing aggregate election results, both at the country-level and at the party-level and compare them with the results of the preceding first-order national election in each EU member country. Our results suggest that the ongoing politicisation of EU politics had little impact on the second-order nature of European Parliament elections.
\end{abstract}

\section{Keywords}

economic crisis; EU policy scope; European Parliament elections; migration; second-order national elections

Issue

This article is part of the issue "How Different Were the European Elections of 2014?", edited by Wouter van der Brug, Katjana Gattermann and Claes de Vreese (University of Amsterdam, The Netherlands).

(C) 2016 by the authors; licensee Cogitatio (Lisbon, Portugal). This article is licensed under a Creative Commons Attribution 4.0 International License (CC BY).

\section{Introduction: Same Question, Different Europe}

Since the very first direct election of the members of the European Parliament (EP) in 1979, the question has been on the table various times: are European Parliament elections still second-order national elections? Is it still mainly national political dynamics that are affecting the voting behaviour of European citizens when they cast their votes in European Parliament elections, or do we find significant traces of EU policy voting? This paper seeks to answer this question for the European Parliament elections of late May 2014.
The European Union of 2014 and the direct elections of its parliament in this year differ from the past in a number of ways. First of all, since the first direct elections, the number of member countries has more than tripled and increased from 9 to 28. Today, the Union includes both the West and the East of the continent, with a lot of variation in electoral and party systems. Secondly, the power of the European Parliament has increased continuously, especially since the Lisbon Treaty. Based on Lisbon stipulations, and for the first time in the history of European Parliament elections, five political groups of the EP offered voters a say re- 
garding the presidency of the EC by nominating their lead-candidates for the position ahead of the election. Thirdly, and perhaps not least importantly, the policy reach of the Union has increased continuously, and steeply, from the 1950s onwards (Wallace \& Wallace, 2007). This can be demonstrated by the number of EUinitiated legislative acts that arrive in national parliaments for ratification. Since this number is roughly (though not exactly, as not every country is part of every treaty) the same for all EU member countries, it may suffice to study its evolution over the years in Germany (Figure 1). It becomes very clear here that the EU has become an ever more important legislator in all of its member-countries, and in quite a wide range of policy domains (Hooghe \& Marks, 2001; Schmitt, 2005).

This is the quantitative aspect of the history of the legislative activity of the European Union. For a more qualitative perspective, it might be useful to concentrate on two major EU political projects: the single European market and, in particular, the open borders policy, and the single European currency and the complementary common monetary policy. Both of these policies are said to have had positive consequences regarding the stimulation of economic growth (European Commission, 2015). However, according to the neo-neo-functionalist theory of European integration (Niemann \& Schmitter, 2009; Schmitter, 2005), they are at the same time likely to have caused unintended political side effects of a more critical nature. With regard to the four freedoms of the single European market-open borders for goods, persons, services and capital-the free movement of persons is said to have posed challenges to national identity (Hooghe \& Marks, 2009) and social security (Kriesi, 2009; Kriesi et al., 2006). On the side of the economic and public debt crisis, and the monetary policies of the Eurozone that were agreed to counter it, it seems that austerity policies imposed by the EU on debtor countries have had electoral consequences, diminishing electoral support for government parties (Magalhães, 2014) and favouring Eurosceptical parties (Kriesi, 2014). For obvious reasons, this has been more profound in Southern Europe (Bosco \& Verney, 2012; Freire, Teperoglou, \& Moury, 2014; Verney \& Bosco, 2013) than elsewhere, but there are also Western European (Alternative für Deutschland) and Northern European (True Finns) examples pointing in that direction.

In this paper, we set out to assess the effects of these EU policies on the results of the European Parliament elections of May 2014. We will do so by comparing EU-policy effects on the support base of political parties with the more conventional second-order elections (SOE) baseline model. We proceed as follows: we first recapitulate the theoretical background of secondorder elections and present the basic hypotheses that are customarily derived from it. We confront these with a set of alternative hypotheses focussing on the potential electoral consequences of EU policy making. Following this, we proceed to briefly present our database, and to test our hypotheses. The last section offers an intermediate conclusion and discusses questions for future research.

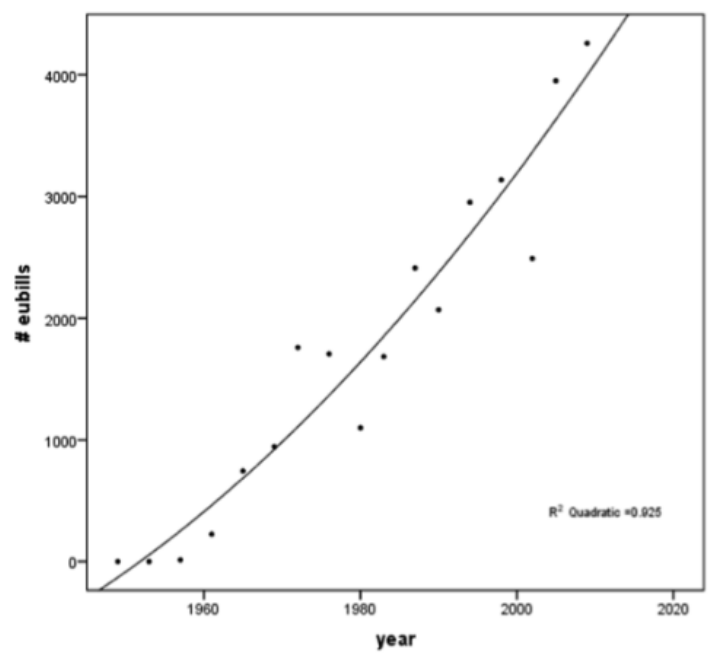

Figure 1. The increase of EU-initiated legislative acts arriving at the German Federal Parliament. Source: Deutscher Bundestag, 2014; Feldkamp, 2010, 2014.

\section{Still Second-Order?}

In the aftermath of the first direct election of the members of the European Parliament in June 1979, the concept of second-order national elections was proposed in order to understand the outcome of these novel kinds of supranational but still "less important" elections (Reif \& Schmitt, 1980). Back then, multi-level governance was novel territory in Europe (arguably with the exception of federal Germany, Spain with its autonomous regions, and the special case of Switzerland). The policy reach of the Union was still limited (see again Figure 1), and the powers of the European Parliament were limited too. In such an environment, EP elections were far from deciding who is "in power" in the European Union (or the European Community as it was called back then). National first-order elections determined the composition of national parliaments and governments, and thereby had an impact on European policy making by affecting the composition of the Council of Ministers. In European Parliament elections, therefore, voters did not cast their votes to choose the best candidates for governing the EU, but they did support or oppose parties and candidates primarily for national reasons (Kuechler, 1991). Characteristic of those second-order elections is that there is less-atstake than in really important elections. The secondorder elections model was developed for Western Europe and amended and revised by various scholars (Ferrara \& Weishaupt, 2004; Marsh, 1998; Norris \& Reif, 1997; Reif, 1984). After the big enlargement of 
the Union in 2004 which incorporated at once eight Eastern European countries plus Cyprus and Malta, things have become more complicated again because of the relative electoral instability of the new Eastern member countries. New research reflecting on those effects has been added to the literature (e.g., Hix \& Marsh, 2011; Koepke \& Ringe, 2006; Schmitt, 2005).

In this paper we analyse the 2014 European Parliament elections in order to see whether they still fit the original claim. While we realise that SOE research has progressed over the years quite considerably-for example with regard to the analysis of micro-foundations of voting behaviour in EP elections (Carrubba \& Timpone, 2005; Hobolt \& Spoon, 2012; Hobolt \& Wittrock, 2011; Schmitt, Sanz, \& Braun, 2009; Weber, 2011) - we believe that the original predictions of the SOE model are still the main manifestation of it. In what follows, we will confront those original predictions with an alternative model that focuses on EU-policies. In the original set of hypotheses based on national politics, a first prediction is that fewer voters participate in these elections simply because there is "less-at-stake". Second-order elections are less politicised and electoral mobilisation is lower than in first-order elections. These reasons behind low participation rates have been investigated in a steadily growing body of research. The results of these studies depend a bit on the research design and the richness of the set of control variables introduced in micro-level models of electoral participation. Overall, the findings suggest that non-voting in European Parliament elections is normally not caused by Euroscepticism and hence not a sign of a legitimacy crisis of the European Union (Franklin, 2001; Schmitt, 2005; Schmitt \& Mannheimer, 1991; van der Eijk \& Schmitt, 2009) but see also Blondel, Sinnott, and Svensson (1998) for the opposite view. This first hypothesis thus predicts:

H1: Participation is lower in EP elections, compared to the preceding national first-order election.

The second prediction of the second-order national election model claims that national government parties do worse compared to national first-order elections since a number of voters will punish them for theunavoidable-disappointments they have caused in the national political arena. This kind of punishment can be realised as vote switching away from government parties (when first-order voters support a party other than the previously chosen government party) or as abstention (when first-order government voters abstain in EP elections).

H2: Government parties' vote shares decline in EP elections, compared to the previous national firstorder election.

In addition, it has been proposed that the size of the government parties' losses follows a pattern which is related to the national electoral cycle. Already in the 1970, US scholars found that the popularity of the US president follows a cyclical pattern with a postelectoral euphoria right after the victory, a decline in popularity roughly until mid-term, and a gradual recovery in the approach to the subsequent on-year election (Campbell, 1993; Stimson, 1976; Tufte, 1975). Similar phenomena has been confirmed for state elections in Germany (Dinkel, 1978; Schmitt \& Reif, 2003), less important elections in Portugal (Freire, 2004), and for byelections in Britain (Norris, 1990). Second-order European Parliament election results were also found to be shaped by the national electoral cycle (Reif, 1984; Reif \& Schmitt, 1980). As first-order national elections are held at different times relative to the date of the EP election, the timing of the latter within the national electoral cycles differs between the EU member countries.

\section{H3: Government parties' losses follow the national} electoral cycle and are more severe towards midterm.

Since second-order elections are "less-important" we assume that there will be less strategic voting than in first-order elections. Strategic voting means that citizens vote for a party other than their most preferred one in order to be able to affect the outcome of the elections (Blais, Nadeau, Gidengil, \& Nevitte, 2001). In the firstorder electoral arena, strategic voting is expected to strengthen the support for larger parties, since they are more likely to govern. Supporting them reduces the danger of wasting one's vote. In second-order elections, however, as there is less-at-stake, the consequences of wasting one's vote are less severe. It is therefore expected that more citizens (in relative terms) cast their vote for smaller parties even if there is no realistic possibility for them to gain parliamentary representation and affect public policy. We therefore expect:

H4: Small parties do better in EP elections, compared to their results in first-order national elections.

Our second set of hypotheses goes beyond the original SOE model and focusses on the impact of EU initiated policies on European Parliament election results. While this possibility was not ignored in the original statement of the model (cf. Reif \& Schmitt, 1980, p. 11), it was certainly less prominent than it is today. This perspective adds another two predictions to the original four as we concentrate here on two key EU policies. Both of them originate in the Single European Market project: the policy of open borders and that of a common currency and hence a common monetary policy.

The first EU-initiated policy with alleged consequences for electoral behaviour originates in one of the 
four liberties of the Single European Market-the free movement of persons (European Union, 2004). As a result of the completion of the Single European Market in general and the Schengen agreement in particular, the open border policy and intra-EU migration has become a salient political issue long before the refugee crisis that dominates the news at the time of writing. Immigration and national identity are particularly salient issues for parties on the right and the extreme right of the political spectrum (Golder, 2003; Meyer \& Rosenberger, 2015; Mudde, 1999; Yilmaz, 2012). As the consequences of the politics of open borders are directly attributable to EU-level policies, our fifth hypothesis predicts:

H5: Parties on the extreme right do better in European Parliament elections as compared to firstorder national elections the higher the share of immigrants is in the national population.

The second EU initiated policy with potential consequences for electoral behaviour is the common monetary policy within the Eurozone, and here in particular the "no bail-out clause" (Art. 125 Lisbon Treaty) which makes it illegal for one EU member country to assume the debts of another. This has to be seen in conjunction with the so-called "stability and growth pact" of the Economic and Monetary Union of which all EU member-countries (members and non-members of the Eurozone) are part. This pact sets upper limits for government deficit ( $3 \% \mathrm{GDP})$ and debt (60\% GDP) which when breached has severe consequences for the fiscal and budgetary autonomy of a member-country. This is the legal basis of the austerity policy of the Eurozone government which in large parts of Southern Europe has caused economic crises, high unemployment (youth unemployment in particular), social unrest and political protest, and electoral realignments. These phenomena were not restricted to bailout countries or countries with extraordinarily high public debt. Ahead of the 2014 elections to the European Parliament, in Greece, Spain, and Portugal-the most prominent debtor countries of the Eurozone-public protests against the austerity policy of the Eurozone government (the "Troika" of European Commission, IMF and $E C B)$ were dominating the news. On the other side of this new economic cleavage in Europe, in the creditor countries, the critique about the risks of the common currency has lent support to new Eurosceptical parties even where nothing like this was known before (as in Germany for example). At the same time, public support for European integration went down dramatically both in debtor countries suffering from economic consequences of severe austerity measures and, somewhat less so, in the creditor countries (Roth, NowakLehmann D., \& Otter, 2013). Given this background, we formulate our final hypothesis as follows:
H6: Compared to their first-order national election results, Eurosceptic parties do better within the Eurozone than outside.

\section{Data and Methods}

We test our hypotheses on the basis of data provided by the European Parliament itself, on its websites reporting on the official results of the 2014 elections (European Parliament, 2014). Comparable information regarding the previous national election results is taken from the "Parties and Elections" database (Nordsieck, 2015). This database provides information on parliamentary elections in European countries since 1945. Immigration rates are from the Eurostat database, $\mathrm{mi}$ gration and migrant population statistics (Eurostat, 2015). Left-right positions and anti-/pro-European integration positions are mean party locations as perceived by their respective national citizenry. In the case of left and right, left is on the low (=zero) side of the scale while right is on the high $(=10)$ side. For the European integration dimension, 0 indicates "integration has gone too far", while 10 indicates "integration should be pushed further". Data are from the $2014 \mathrm{Eu}$ ropean Election Study (EES) surveys, first and second waves (Schmitt, Hobolt, \& Popa, 2015). We use the effective number of electoral parties (ENEP) index to determine the format of a party system in consecutive first-order and second-order elections (Laakso \& Taagepera, 1979). As will be discussed in detail below, we use this index to test H4. The dataset of Gallagher provides ENEP data for national elections (Gallagher, 2014) and the same formula has been used to calculate comparable data for European Parliament elections.

National-level hypotheses are tested in a bivariate manner, by plotting FOE results against EP election results (e.g. for turnout, government party support, etc.) This step of the analysis is based on 28 cases (member countries). Party-level hypotheses are tested in a multilevel model using the Ime4 package of $R$ (version 1.1-7) with 160 cases (parties represented in the European Parliament) on the first level and 28 cases (member countries) on the second.

\subsection{Was Participation Lower?}

One of the most fundamental assumptions of the second-order elections model is that participation is lower compared to first-order elections, since politicisation and electoral mobilisation is deficient. In addition to the unfavourable comparison with turnout rates at first-order elections, a steady decrease was observed in the participation in EP elections since $1979 .{ }^{1}$

1 The EU-wide turnout rates for the EP elections were: $62 \%$ in $1979,59 \%$ in $1984,58 \%$ in $1989,57 \%$ in $1994,50 \%$ in 1999 , $45 \%$ in 2004, 43\% in 2009 and finally again 43\% in 2014 . 
Was turnout in the 2014 election lower than in the preceding first-order election? In order to test this expectation against reality, we compare the respective turnout levels. Figure 2 shows the results of this analysis. We find that participation in the 2014 EP elections is systematically lower than it was in the preceding FOEs of the member states. Exceptions to this rule are Belgium and, to a lesser degree, Luxembourg. Belgium and Luxembourg are organising general elections under a compulsory voting regime, though in Luxembourg this applies only to citizens under 75 years of age. This is why participation in these two countries is about as high as it was in the previous national elections-there is no additional electoral mobilisation necessary there.

In addition to this, Belgium ran simultaneously firstorder elections and provincial elections together with the election of the members of the European Parliament. Surprisingly enough, the recorded participation rate for the Belgian EP election is 90 per cent, while it is 88.5 for the simultaneous national first-order election. Belgium then is the only country with a somewhat higher turnout rate in the EP election. Another country that does not really meet our expectations is Greece (EL=Ellada) where electoral participation was very close (only 2.5 per cent lower) to the level of the previous election of the members of the national parliament. As Greece was (and still is) one of the hardest-hit countries in the current financial crisis, we might see this as an indication that the Euro crisis has contributed to the politicisation of EU policies and hence to electoral mobilisation there.

Furthermore there are huge differences in partici- pation rates between member countries. The five countries with the lowest participation are all Eastern European which share a communist background of unfree elections. The lowest participation rate of all is recorded in Slovakia with only 13.05 per cent. This is the lowest rate ever recorded in a European Parliament election. Slovakia is followed by the Czech Republic with 18.2 per cent, Poland with 23.83 per cent, Slovenia with 24.55 per cent, and Croatia with 25.06 per cent. The highest participation rates among member states, after Belgium and Luxembourg, are recorded in Malta, Greece, Italy, Denmark and Ireland. It is important to underline that there are three crisis countries in the list, even if participation rates were lower than in national elections. The Eurozone crisis and the subsequent politicisation of EU policies seem to have stimulated electoral participation (see Appendix for a detailed table of participation rates).

\subsection{Did Government Parties Lose?}

Another central prediction of the second-order elections model is that governing parties lose support while opposition parties win. These kinds of elections, it is argued, are frequently used to punish the parties of the incumbent government. In EP election of 2014, this prediction is valid for 20 of the 28 member countries. In four cases (Austria, Belgium, Finland, and Lithuania), governing parties (including parties participating in government coalitions) were able to gain a modestly higher proportion of the valid vote compared to what they had in the last first-order election;

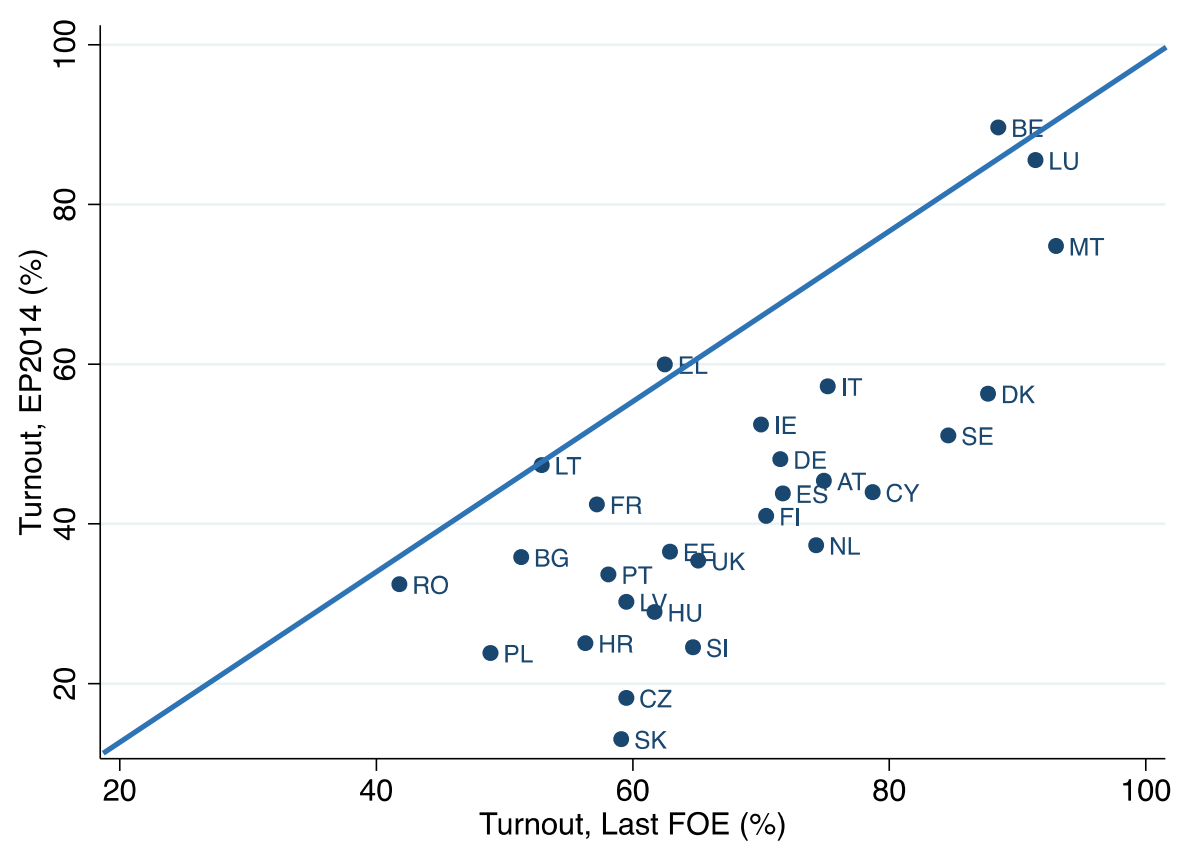

Figure 2. Participation rates in the European Election of 2014 and the preceding FOE. 
however the difference in each case is small-less than 3 per cent on average. Two other cases are Hungary and Italy. Hungary ran national elections in April 2014, and the European Parliament election was organised very shortly thereafter. This seems to be a clear case of a post-electoral euphoria. In Italy, the case is similar in substance but somewhat different in the proceedings. The Italian government changed its Prime Minister in February 2014. The positive resonance of the incoming new, young, and energetic leader can therefore be equally understood as a source of post-electoral euphoria (Segatti, Poletti, \& Vezzoni, 2015). Figure 3 shows vote shares of government parties in the 2014 European Parliament elections and the preceding firstorder national election.

The case of Latvia is another exception to the second-order rule of government losses in second-order elections. Three years after the previous first-order election the governing coalition increased its share of votes. This again has a simple and straightforward explanation: Latvia went through a Prime Minister (PM) change in January 2014. The country's new PM, Laimdota Straujuma was backed by an expanded four-party coalition, including the Unity, two Green parties, and the National Alliance (The Economist, 2014).

Turning to the final exception of Slovenia we note that the country ran early elections in July 2014-one month after the EP election in May-after the resignation of the previous government in May. So we assume that the political verdict about the new government was already taken at the moment of the European Parliament election and the subsequent national first- order election was only rubber-stamping the decision from late May.

\subsection{Do Government Losses Follow the National Electoral Cycle?}

The second-order elections model not only claims that governments are expected to lose support in these kinds of elections, it also claims that these losses follow the first-order electoral cycle. We have already referred to this cycle when talking about post-electoral euphoria. Earlier research has shown that this regularity is less visible in the new member countries from Eastern Europe (Schmitt, 2005). This was understood as resulting from a lesser degree of saturation of the post-communist party systems originating from the much weaker ties between voters and parties (Schmitt \& Scheuer, 2012).

Figure 4 identifies a modest relationship between the differences in governing parties (or coalitions) vote shares and the proportion of national electoral cycle that was completed at the time when the 2004 EP election was held.

We find the expected curvilinear pattern: on average, governing parties lose most around midterm, and do comparatively better shortly after the last and shortly ahead of the next first-order election. There are a lot of cases that do not really follow that pattern, and the relationship is therefore not very strong. However, it is stronger in the West of Europe with its wellestablished party systems than it is in the much younger and weaker party systems of the new democracies in the East (as is shown in the Appendix to this paper).

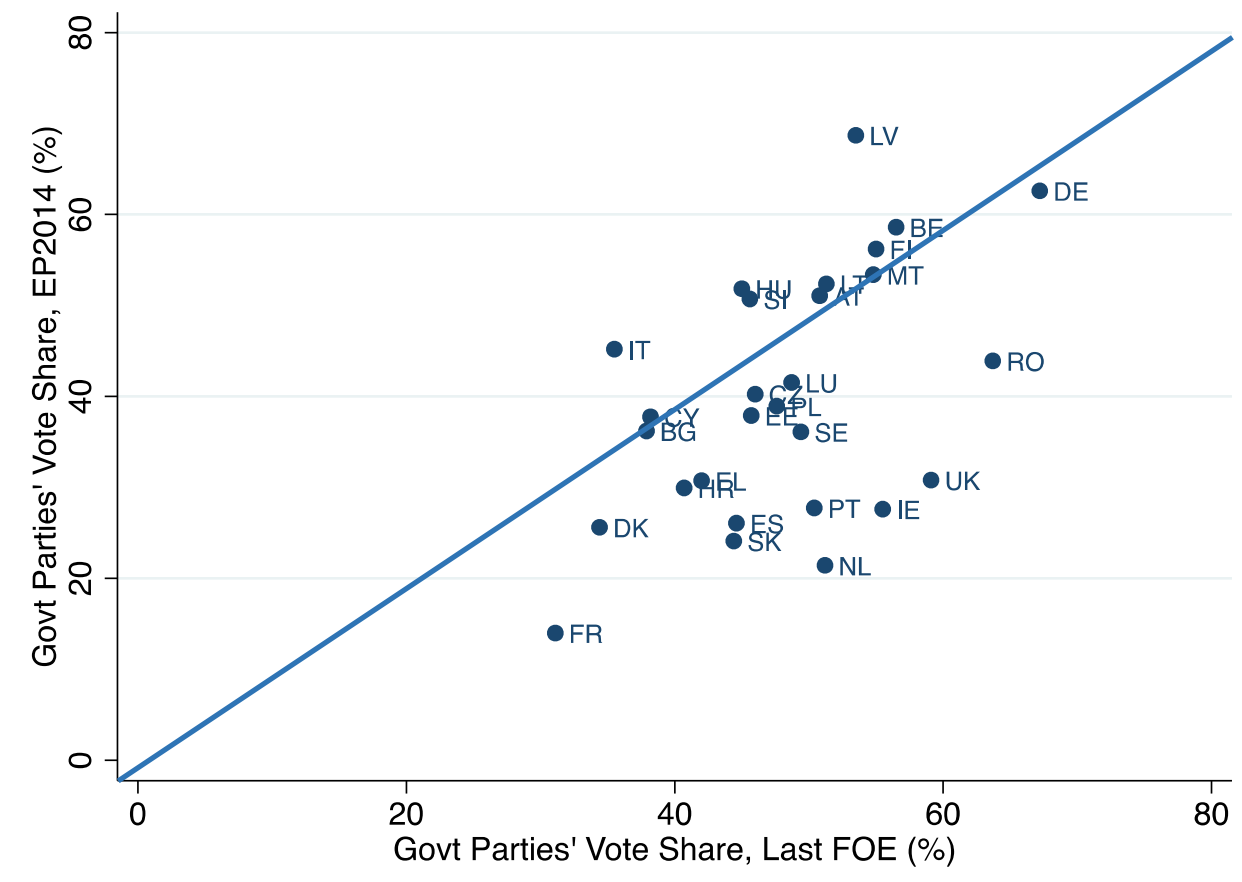

Figure 3. Vote share of government parties in the 2014 European Election compared to the preceding first-order national election. 


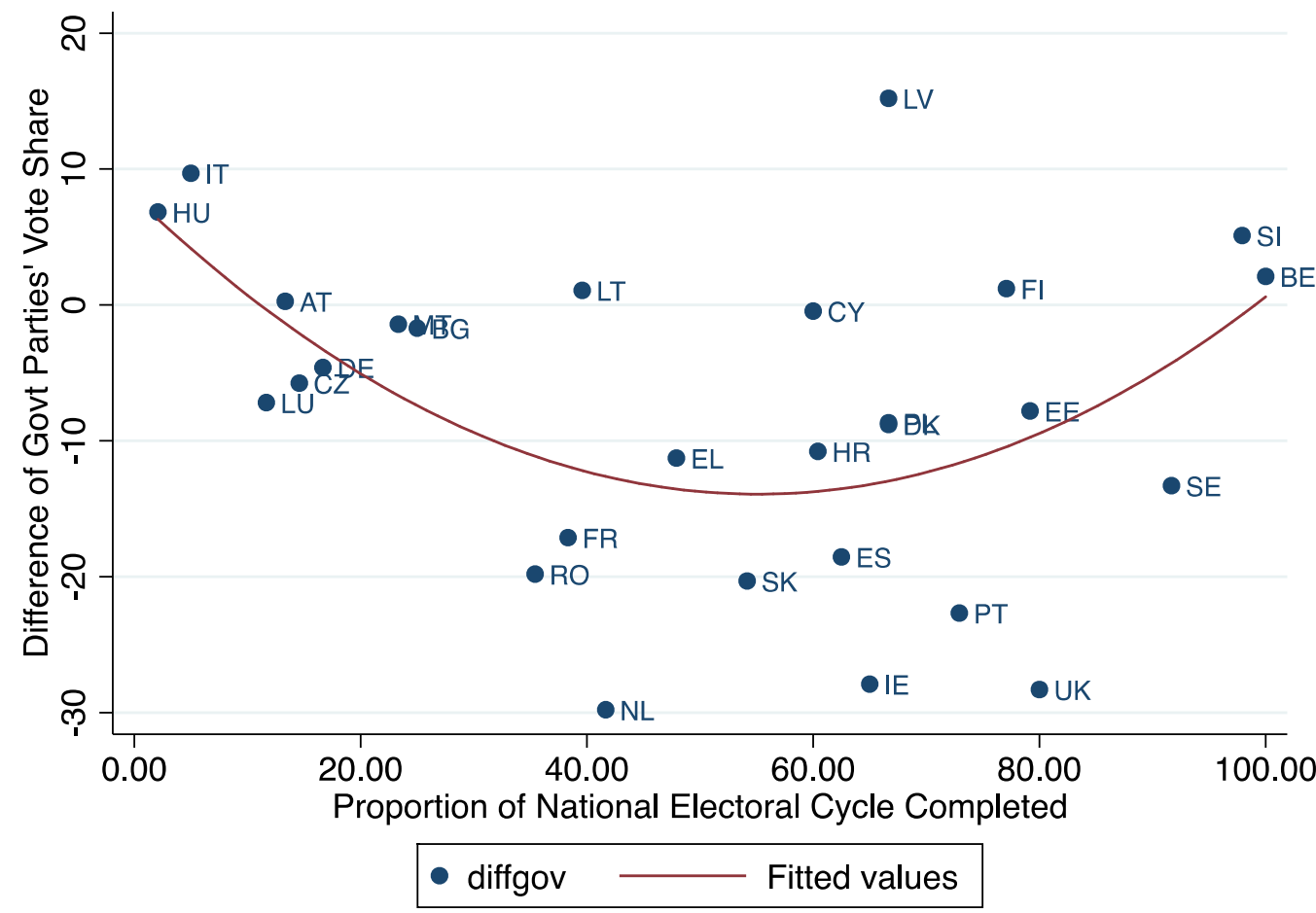

Figure 4. The electoral cycle and vote difference of the governing parties.

\subsection{Do Big Parties Lose?}

The last, but certainly not the least important assumption of the second-order elections model is related to the prevalent mechanism of vote choice. There are two basic mechanisms-sincere and strategic voting (Alvarez \& Nagler, 2000). The model claims that, since there is less-at-stake, citizens have less of an incentive to vote strategically. Instead, they are free to cast their vote in a sincere manner and support their first electoral preference, rather than another (larger, stronger, more likely to govern) party for deliberate reasons. For testing the hypothesis, we need to discriminate small parties from large parties. There is no consensus however on the issue of at what proportion of votes small parties end and large parties begin. For this reason, we compare the effective number of electoral parties (ENEP) in a party system both at the EP election and at the previous first-order election. Comparing these two numbers, we expect the index value for the European Parliament elections to be larger-thus indicating a larger number of effective parties in second-order elections. Figure 5 shows the results of this comparison.

Small parties did better in almost all of the EU members, sometimes considerably better. Spain is the first country to mention here since the ENEP has increased by 3.42 points. Even if the reasons are complex and require further study (Cordero \& Montero, 2015), we are tempted to speak about a party system change and are not surprised that the significance of smaller parties continued in the 2015 national first-order elec- tion. The Netherlands follows Spain, with a 3.06 increase in the effective number of parties compared to the 2012 elections.

We can also see that in Romania and Sweden small parties did better. However, there are also some borderline countries, such as Austria, Germany, Luxembourg, and Lithuania in which the ENEP number remained effectively unchanged. Only in Croatia, Italy and Latvia there is a certain decline in ENEP from the national elections to the 2014 European Parliament election, these are the countries that do not support the prediction. Overall, however, the large majority of countries support the theoretical expectation.

\subsection{Do EU Policies Affect the Vote in EP Elections?}

We turn to testing our two final hypotheses. They state that parties on the right gain in EP elections when immigration is high (H5), and that Eurosceptical parties gain in EP elections when the country belongs to the Eurozone (H6). The dependent variable here is the percentage point gain (or loss) of a party in the European Parliament election of 2014 compared to its result in the last national election. We test these expectations in such a way that their additional contribution (in addition to the indicators specified by the SOEs model) to our understanding of the EP election results is identified (Table 1).

Before we turn to testing these hypotheses, we first have a look at the performance of our well-known SOE indicators in this party-level analysis. What we find 


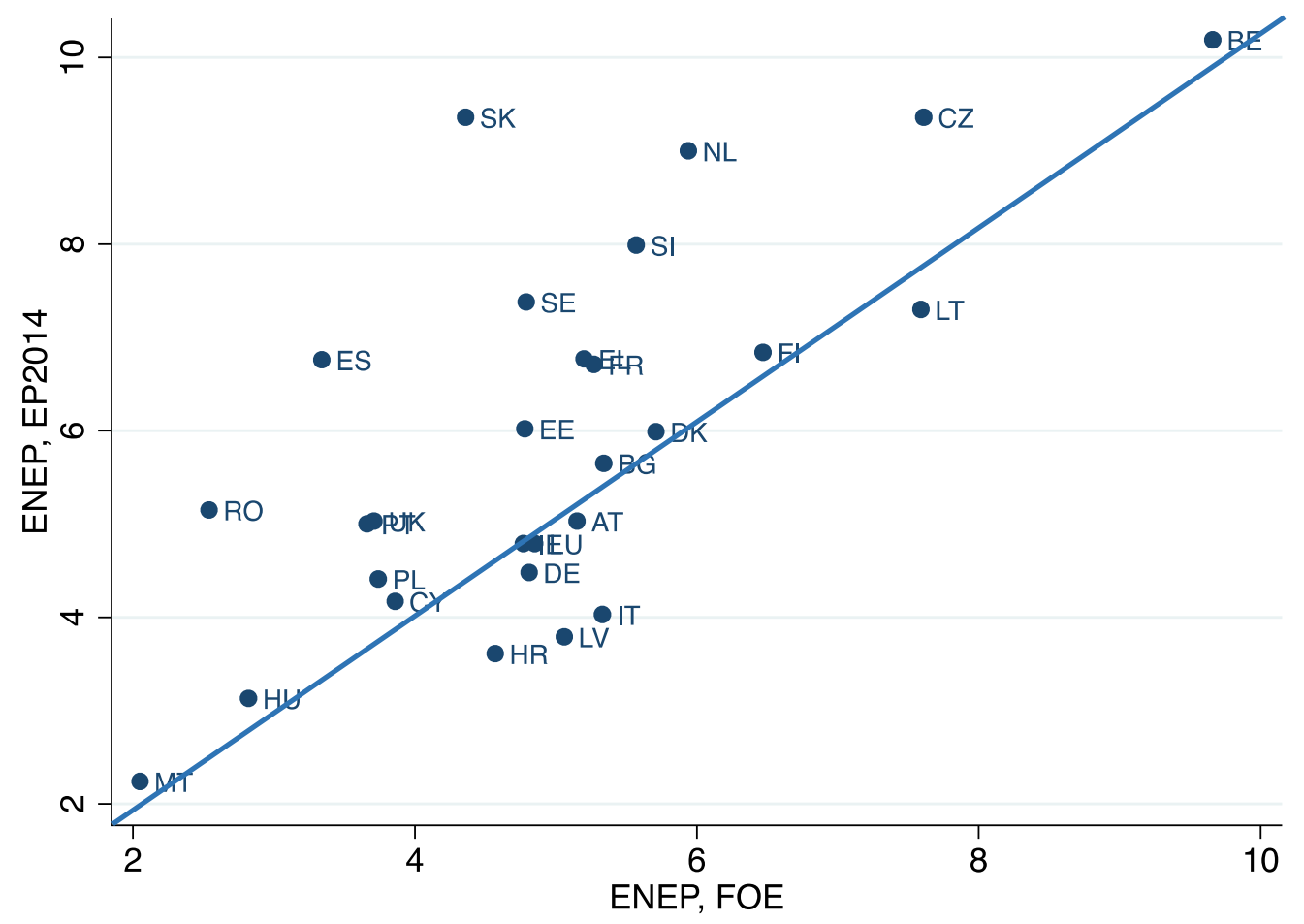

Figure 5. Effective number of parties: EP2014 and the preceding first-order national election.

Table 1. Explaining parties' gains and losses from the preceding first-order election to the European Election of 2014: A multivariate perspective.

\begin{tabular}{lccc}
\hline & Model 1: Empty model & Model 2: Basic model & Model 3: Full model \\
\hline Fixed effects & & & \\
Intercept & $-0.134(0.556)$ & $2.471(3.098)$ & $5.121^{* * *}(1.391)$ \\
Electoral cycle & & $-0.010(0.041)$ & $-0.022(0.039)$ \\
Party in government & & $-5.291^{* *}(2.135)$ & $-4.807^{* *}(2.092)$ \\
Party size & & $-0.315^{* * *}(0.043)$ & $-0.301^{* * *}(0.042)$ \\
Party left-right position & $0.394(0.276)$ & $0.378(0.316)$ \\
Party EU support & & $0.033(0.500)$ & $-1.971^{* *}(0.899)$ \\
Share of migrants in country & & $0.037(0.074)$ & $0.038(0.070)$ \\
Eurozone member & & $0.008(0.979)$ & $0.194(0.913)$ \\
Cycle * government & & $0.166^{* *}(0.072)$ & $0.154^{* *}(0.072)$ \\
Left-right pos'n * migration & & & $-0.007(0.054)$ \\
EU support * Eurozone & & & $2.878^{* *}(1.046)$ \\
Random effects (variance) & & & \\
Intercept & & 2.042 & 0.846 \\
Left-right position & & 0.666 & 1.879 \\
EU support & & 1.117 & 1.218 \\
Residuals & & 30.250 & 27.786 \\
N party/country & $159 / 28$ & $159 / 28$ \\
Log Likelihood & & -500 & -593 \\
AlC & $159 / 28$ & 1032 & 1027 \\
\hline
\end{tabular}

Note: ${ }^{*}$ denotes $p<0.1 ;{ }^{* *}$ denote $p<0.05 ;{ }^{* * *}$ denote $p<0.005$. All country-level variables (i.e. share of migrants) are grand mean centred. All level 1 variables with random slopes (i.e. left-right position and EU support) are group mean centred. 
is quite comforting: the factors of the SOEs model work well at the party-level and confirm our insights from the country-level analysis. We see that small parties win-the larger the party, the higher the losses in EP elections; this is in fact our strongest effect. We also find that national government parties lose in European elections; this effect is statistically significant but considerably weaker compared to the size effect. And last but not least, we find that government parties' losses are moderated by the position of the EP election in the national electoral cycle-they do relatively better, the further away the EP election is to national midterm; this is again a somewhat more modest but statistically significant effect. Model 2 includes, in addition, a number of main effect variables (like share of immigrants and left-right position of party) for merely statistical reasons-we are only interested in their interaction with one another and will not consider them in any greater detail here.

\subsection{Do Parties on the Right Win in EP Elections When the Share of Immigrants in a Country Is High?}

We do not find any trace of such a mechanism. The interaction between the left-right position of a political party and the proportion of immigrants is not only insignificant but its miniscule effect is also pointing in the wrong direction. It could of course be that this interaction is superseded by the party size variable and manifest itself if the latter would be omitted as a control variable. However, party size is a much more general factor at work on the left and the right.

So we conclude that the free movement of people as one of the core freedoms of the Single European
Market does not benefit the parties on the right in particular. But why then have UKIP and FN had such a spectacular result in the 2014 EP election? Part of an answer could be that different electoral systems are used in national and EP elections in both countriesand that majoritarian systems as applied in national first-order elections in both Britain and France benefit large, centrist parties. Another part could be the weakness of the national government in both countries at the time of the election. However, both arguments do not point to the domain of EU policy making.

\subsection{Do Eurosceptic Parties Win If They Compete Within a Eurozone Country?}

This is our second EU policy based hypothesisEurosceptical parties are expected to win in EP elections as a result of the frictions around the public debt crisis in large parts of the South of the Union. A first quick look at the respective coefficient in Model 3 of Table 1 seems to support the expectation. However, plotting the relative electoral gains and losses of political parties for both Eurozone members and nonmembers tells us something else (Figure 6).

What we see here is that within the Eurozone, Eurosceptical parties are doing somewhat worse in EP elections than they have done in the previous national first-order election. This effect is very weak and statistically not significant. Outside the Eurozone, however, we find a quite strong opposite effect: Eurosceptical parties do considerably better in EP elections than they have done in the previous national first-order election. In 2014, the turmoil within the Eurozone benefitted Eurosceptic parties of countries that were not part of it.

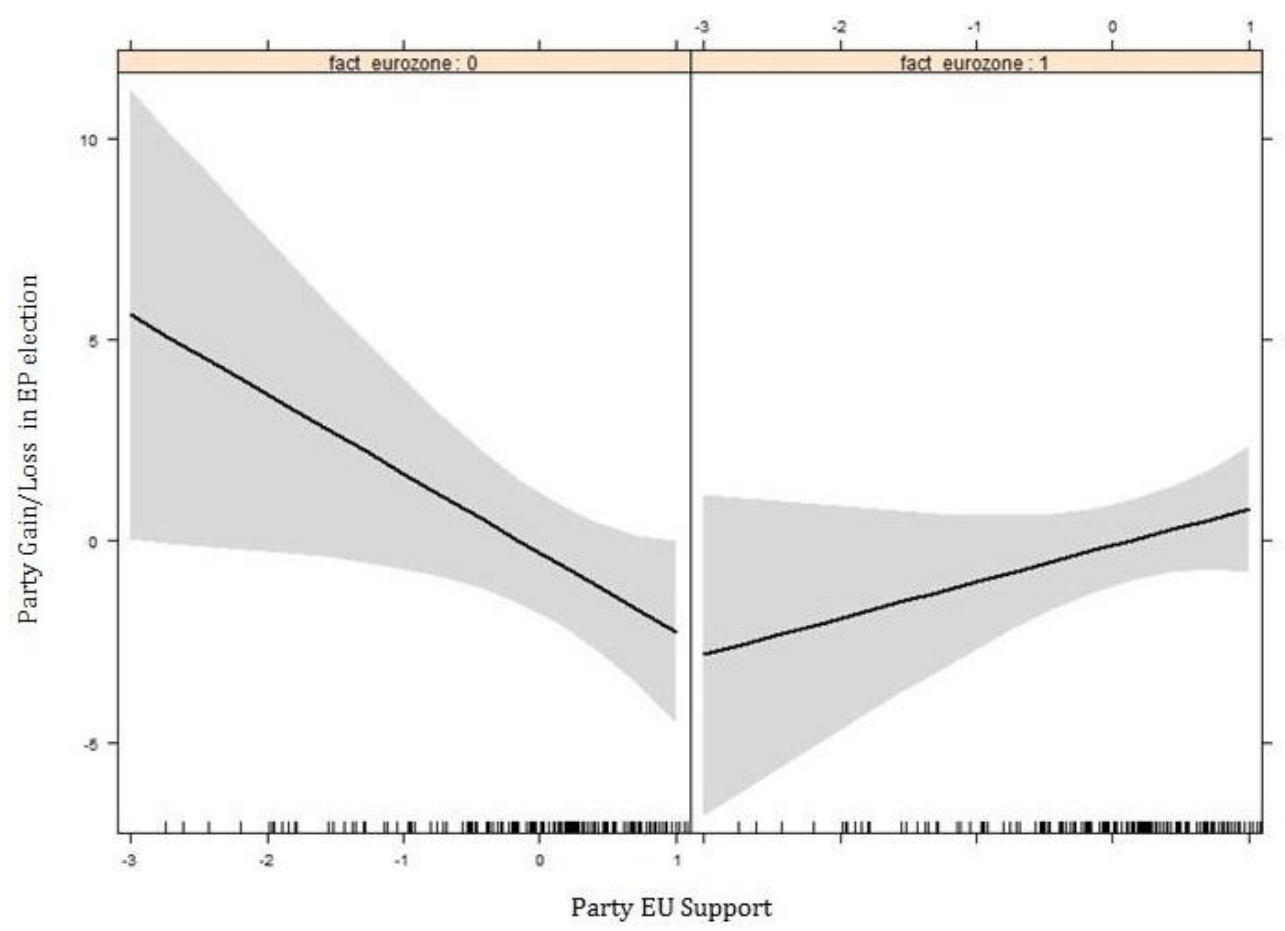

Figure 6. Predicted gain-loss of political parties by their EU support within and outside the Eurozone. 


\section{Conclusion}

This article aims to understand the main dynamics in the 2014 elections of the members of the European Parliament. Two rival expectations are investigatedthe second-order national elections model and the EU policy scenario.

According to the first, European citizens decide about their representatives in Brussels mainly according to national criteria. From Reif and Schmitt (1980) onwards, various authors have assessed the "secondorderness" of EP elections, mostly confirming the original predictions. This paper asks the same question for the May 2014 elections, which were held after six years of economic crisis and various political changes in Europe.

According to the second scenario, citizens are impressed by the consequences of the growing scope of EU policy making (we concentrate here on intra EU migration and the Eurozone crisis) and support Eurosceptical parties as a consequence in European Parliament elections. In this second view, it is the policies of the European Union-more specifically the Single European Market and the European Monetary Union - that offers the main stimulus for electoral behaviour, not the national political process.

After testing the second-order elections assumptions, we conclude that in general they still hold. The first prediction we have tested is that participation is lower in EP elections compared to the preceding FOEs in the member-countries. We found it is still valid. The only country where some doubts arose is Greece where electoral participation in the EP election was very close to the participation rate in the preceding FOE.

Another important assumption of the model is that government parties (or members of government coalitions) lose support. This prediction holds up as well, but there are a number of deviant cases. Some of them can be explained as post-election euphoria, while others require further investigation. When we look for the relationship between these losses and the national electoral cycle we conclude that governing parties lose the most at around midterm and do comparatively better shortly after and ahead of subsequent elections. The national electoral cycle is still a stronger moderator of government parties' losses in the consolidated party systems of Western Europe as compared to the postcommunist party systems of Eastern Europe. The fourth assumption was that small parties do better in the EP elections. This was also corroborated. In most of the Member States the "effective numbers of electoral parties" (ENEP) is higher in EP elections than it is in national first-order elections. Among the larger consolidated electoral systems under study, the special case of Spain needs to be mentioned here. In Spain, the effective number of parties rose to 3.42 index points, which might well point towards a severe party system change.
So the "second-orderness" of European Parliament elections, in its main aspects, has again been confirmed. Does this also mean that the EU policy scenario failed to inform our understanding of the 2014 EP election results? This is what we find in our exemplary analysis. Parties on the right do not gain more support under conditions of high immigration; and Eurosceptic parties do not systematically gain more support within the Eurozone versus outside of it-on the contrary, the opposite seems to be the case.

All in all, we can say that the assumptions of the second-order elections model are still valid. The 2014 European Parliament elections were second-order elections, and the politicisation of European Union politics did not really discourage the predictions of the second-order model. The "indirect" election of the President of the European Commission in the course of the 2014 European Parliament election-which has been referred to as the Spitzenkandidaten plot (Schmimmelpfennig, 2014)-did not change the institutional context in such a way that these elections would have lost their second-order character. However, future research will have to have an eye on these developments.

\section{Acknowledgements}

We wish to thank the editors of this issue for their patience and advice, and two anonymous referees for their most helpful comments and suggestions. A special thank you goes to our colleague Sebastian A. Popa for his generous support regarding the multilevel modeling in the party-level regressions. All remaining errors are ours of course.

\section{Conflict of Interests}

The authors declare no conflict of interests.

\section{References}

Alvarez, R. M., \& Nagler, J. (2000). A new approach for modelling strategic voting in multiparty elections. British Journal of Political Science, 30(1), 57-75.

Blais, A., Nadeau, R., Gidengil, E., \& Nevitte, N. (2001). Measuring strategic voting in multiparty plurality elections. Electoral Studies, 20(3), 343-352.

Blondel, J., Sinnott, R., \& Svensson, P. (1998). People and Parliament in the European Union. Oxford: Clarendon Press.

Bosco, A., \& Verney, S. (2012). Electoral epidemic: The political cost of economic crisis in Southern Europe, 2010-11. South European Society and Politics, 17(2), 129-154.

Campbell, J. E. (1993). The presidential pulse of Congressional elections. Lexington: University Press of Kentucky. 
Carrubba, C., \& Timpone, R. J. (2005). Explaining vote switching across first- and second-order elections evidence from Europe. Comparative Political Studies, 38(3), 260-281.

Cordero, G., \& Montero, J. R. (2015). Against bipartyism, towards dealignment? The 2014 European election in Spain. South European Society and Politics, 20(3), 357-379.

Deustcher Bundestag. (2014). Datenhandbuch 19492003. Retrieved from https://www.bundestag.de/ dokumente/datenhandbuch/datenhandbuch_archiv

Dinkel, R. (1978). The relationship between federal and state elections in West Germany. In M. Kaase \& K. von Beyme (Eds.), Elections and parties. London: Sage Publications.

European Commission. (2015). Economic and monetary union. European Commission. Retrieved from http:// ec.europa.eu/economy_finance/euro/emu/index_en .htm

European Parliament. (2014). Results of the 2014 European elections. European Parliament. Retrieved from http://www.europarl.europa.eu/elections2014results/en/election-results-2014.html

European Union. (2004). Directive 2004/38/EC. Retrieved from http://eur-lex.europa.eu/LexUriServ/ LexUriServ.do?uri=OJ:L:2004:158:0077:0123:en:PDF

Eurostat. (2015). Migration and migrant population statistics. Eurostat. Retrieved from http://ec.europa.eu/ eurostat/statistics-explained/index.php/Migration_ and_migrant_population_statistics

Feldkamp, M. F. (2010). Deutscher Bundestag 1990 bis 2009: Parlaments-und Wahlstatistik für die 12 . bis 17. Wahlperiode. Zeitschrift für Parlamentsfragen, 317.

Feldkamp, M. F. (2014). Deutscher Bundestag 1994 bis 2014: Parlaments-und Wahlstatistik für die 13. bis 18. Wahlperiode. Zeitschrift für Parlamentsfragen, 316.

Ferrara, F., \& Weishaupt, J. T. (2004). Get your act together: Party performance in European Parliament elections. European Union Politics, 5(3), 283-306.

Franklin, M. (2001). How structural factors cause turnout variations at European Parliament elections. European Union Politics, 2(3), 309-328.

Freire, A. (2004). Second-order elections and electoral cycles in democratic Portugal. South European Society and Politics, 9, 54-79.

Freire, A., Teperoglou, E., \& Moury, C. (2014). Awakening the sleeping giant in Greece and Portugal? Elites' and voters' attitudes towards EU integration in difficult economic times. South European Society and Politics, 19(4), 477-499.

Gallagher, M. (2014). Electoral systems. Trinity College Dublin. Retrieved from: http://www.tcd.ie/Political_S cience/staff/michael_gallagher/ElSystems/index.php

Golder, M. (2003). Explaining variation in the success of extreme right parties in Western Europe. Compara- tive Political Studies, 36(4), 432-466. doi:10.1177/ 0010414003251176

Hix, S., \& Marsh, M. (2011). Second-order effects plus pan-European political swings: An analysis of European Parliament elections across time. Electoral Studies, 30(1), 4-15.

Hobolt, S., \& Spoon, J.-J. (2012). Motivating the European voter: Parties, issues, and campaigns in European Parliament elections. European Journal of Political Research, 51(6), 701-727.

Hobolt, S., \& Wittrock, J. (2011). The second-order election model revisited: An experimental test of vote choices in European Parliament elections. Electoral Studies, 30(1), 29-40.

Hooghe, L., \& Marks, G. (2001). Multi-level governance and European integration. Oxford: Rowman \& Littlefield Publishers.

Hooghe, L., \& Marks, G. (2009). A postfunctionalist theory of European integration: from permissive consensus to constraining dissensus. British Journal of Political Science, 39(1), 1-23.

Koepke, J. R., \& Ringe, N. (2006). The second-order election model in an enlarged Europe. European Union Politics, 7(3), 321-346.

Kriesi, H. (2009). A postfunctional theory of European integration: From permissive consensus to constraining dissensus. British Journal of Political Science, 39(1), 221-224.

Kriesi, H. (2014). The political consequences of the economic crises in Europe: Electoral punishment and popular protest. In N. Bermeo \& L. M. Bartels (Eds.), Mass politics in tough times: Opinions, votes and protest in the Great Recession. Oxford: Oxford University Press.

Kriesi, H., Grande, E., Lachat, R., Dolezal, M., Bornschier, S., \& Frey, T. (2006). Globalization and the transformation of the national political space: Six European countries compared. European Journal of Political Research, 45(6), 921-956. Retrieved from http:// dx.doi.org/10.1111/j.1475-6765.2006.00644.x

Kuechler, M. (1991). Issues and voting in the European elections 1989. European Journal of Political Research, 19(1), 81-103.

Laakso, M., \& Taagepera, R. (1979). "Effective number" of parties: A measure with application to West Europe. Comparative Political Studies, 12(1), 3-27.

Magalhães, P. (2014). Introduction: Financial crisis, austerity, and electoral politics. Journal of Elections, Public Opinion \& Parties, 24(2), 125-133.

Marsh, M. (1998). Testing the second-order election model after four European elections. British Journal of Political Science, 28, 561-607.

Meyer, S., \& Rosenberger, S. (2015). Just a shadow? The role of radical right parties in the politicization of immigration, 1995-2009. Politics and Governance, 3(2), 1-17.

Mudde, C. (1999). The single-issue party thesis: Extreme 
right parties and the immigration issue. West European Politics, 22(3), 182-197.

Niemann, A., \& Schmitter, P. (2009). Neofuncionalism. In A. Wiener \& T. Diez (Eds.), European integration theory. Oxford: Oxford University Press.

Nordsieck, W. (2015). Parties \& Elections in Europe. Parties and Elections in Europe. Retrieved from http://www.parties-and-elections.eu

Norris, P. (1990). British by-elections: The volatile electorate. Oxford: Oxford University Press.

Norris, P., \& Reif, K. (1997). Second-order elections. European Journal of Political Research, 31(1), 109-124.

Reif, K. (1984). National election cycles and European elections, 1979 and 1984. Electoral Studies, 3(3), 244-255.

Reif, K., \& Schmitt, H. (1980). Nine second-order national elections: A conceptual framework for the analysis of European election results. European Journal of Political Research, 8(1), 3-44. Retrieved from http://dx. doi.org/10.1111/j.1475-6765.1980.tb00737.x

Roth, F., Nowak-Lehmann D., F., \& Otter, T. (2013). Crisis and trust in national and European Union institutions: Panel evidence for the EU, 1999 to 2012 (EUI Working Paper RSCAS 2013/31). Florence, Italy: European University Institute.

Schmimmelpfennig, F. (2014). The Spitzenkandidaten plot: the European Parliament as a strategic competence-maximizer. Europe Debate. Retrieved from http://europedebate.ie/spitzenkandidaten-ploteuropean-parliament-strategic-competencemaximizer/ - sthash.ppMFr4IN.dpuf

Schmitt, H. (2005). The European Parliament elections of June 2004: Still second-order? West European Politics, 28(3), 650-679.

Schmitt, H., Hobolt, S., \& Popa, S. A. (2015). European election study 2014, voter study. doi:10.4232/1.5161

Schmitt, H., \& Mannheimer, R. (1991). About voting and non-voting in the European Parliament elections of June 1989. European Journal of Political Research, 19, 31-54.

Schmitt, H., \& Reif, K. (2003). Der Hauptwahlzyklus und die Ergebnisse von Nebenwahlen. In A. Wust (Ed.), Politbarometer (pp. 239-254). Opladen, Germany: Leske Budrich.
Schmitt, H., Sanz, A., \& Braun, D. (2009). Motive individuellen Wahlverhaltens in Nebenwahlen: Eine theoretische Rekonstruktion und empirische Überprüfung. In Wahlen und Wähler (pp. 585-605). Berlin, Germany: Springer VS.

Schmitt, H., \& Scheuer, A. (2012). Parteien und Wahlen. In S. Keil \& J. van Deth (Eds.), Metamorphosen (pp. 209-236). Baden-Baden: Nomos.

Schmitter, P. C. (2005). Ernst B. Haas and the legacy of neofunctionalism. Journal of European Public Policy, 12(2), 255-272.

Segatti, P., Poletti, M., \& Vezzoni, C. (2015). Renzi's honeymoon effect: The 2014 European election in Italy. South European Society and Politics, 20(3), 311-331.

Stimson, J. A. (1976). Public support for American presidents. A cyclical model. Public Opinion Quarterly, 40(1), 1-21.

The Economist. (2014, January 11). New currency, new leader. The Economist. Retrieved from http://www. economist.com/news/europe/21593502-latvias-pres ident-nominates-laimdota-straujuma-prime-minister -new-currency-new-leader

Tufte, E. R. (1975). Determinants of the outcomes of midterm congressional elections. Americal Political Science Review, 69, 812-826.

van der Eijk, C., \& Schmitt, H. (2009). Legitimacy and electoral abstentions in European Parliament elections. In J. Thomassen (Ed.), The legitimacy of the European Union after enlargement (pp. 208-224). Oxford: Oxford University Press.

Verney, S., \& Bosco, A. (2013). Living parallel lives: Italy and Greece in an age of austerity. South European Society and Politics, 18(4), 397-426.

Wallace, H., \& Wallace, W. (2007). Overview: The European Union, politics and policy making. In Handbook of European Union politics (pp. 339-358). London, New Dheli: Thousand Oaks, Sage.

Weber, T. (2011). Exit, voice, and cyclicality: A micrologic of midterm effects in European Parliament elections. American Journal of Political Science, 55(4), 907-922.

Yilmaz, F. (2012). Right-wing hegemony and immigration: How the populist far-right achieved hegemony through the immigration debate in Europe. Current Sociology, 60(3), 368-381.

\section{About the Authors}

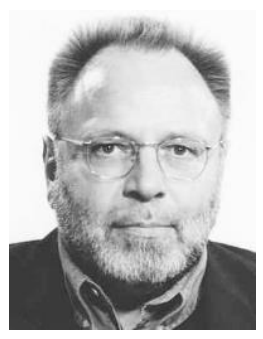

\section{Dr. Hermann Schmitt}

Hermann Schmitt is a Professor of Political Science. He holds a Chair in Electoral Politics at the University of Manchester and is a research fellow of the MZES and a Professor at the University of Mannheim. He has been participating in a number of comparative projects; perhaps most important is his involvement, from 1979 on, in the series of European Election Studies. He received substantial research grants from European, German and British institutions. He is the author and editor of numerous books and articles on electoral behavior in multilevel-systems and on political representation in the European Union. 


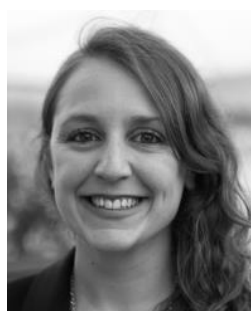

\section{Ilke Toygür}

Ilke Toygür is a PhD Candidate at Universidad Autónoma de Madrid (UAM), Department of Political Science and International Relations and a Mercator-IPC Fellow in Istanbul Policy Center, Sabancı University. Her main academic research areas include European Union integration, political parties, and elections in Europe. She has been teaching various courses including "Elections and Political Behaviour" and "Politics and Government in the European Union" both in English and in Spanish. She has been a visiting researcher in the European University Institute, Florence and MZES, University of Mannheim. 


\section{Appendix}

Table A1. Turnout rates in FOEs and EP Elections. Source: http://www.parties-and-elections.eu

\begin{tabular}{|c|c|c|c|c|}
\hline Country & Turnout FOE (Year) & Turnout EP2009 & Turnout FOE (Year) & Turnout EP2014 \\
\hline AT & 78.8 (2008) & 45.97 & $74.9(2013)$ & 45.39 \\
\hline BE & 91.1 (2007) & 90.39 & 88.5 (2014) & 89.64 \\
\hline BG & 60.2 (2009) & 38.99 & $51.3(2013)$ & 35.84 \\
\hline $\mathrm{HR}$ & 59.5 (2007) & 20.84 & $56.3(2011)$ & 25.06 \\
\hline $\mathrm{CY}$ & 89 (2006) & 59.4 & 78.7 (2011) & 43.97 \\
\hline $\mathrm{CZ}$ & 64.5 (2007) & 28.22 & 59.5 (2013) & 18.2 \\
\hline DK & 86.5 (2006) & 59.54 & 87.7 (2011) & 56.3 \\
\hline $\mathrm{EE}$ & $61(2007)$ & 43.9 & $62.9(2011)$ & 36.52 \\
\hline $\mathrm{FI}$ & 67.9 (2007) & 38.6 & 70.4 (2011) & 41 \\
\hline FR & $60.2(2007)$ & 40.63 & $57.2(2012)$ & 42.43 \\
\hline $\mathrm{DE}$ & 70.8 (2009) & 43.27 & 71.5 (2013) & 48.1 \\
\hline EL & 70.92 (2009) & 52.61 & 62.5 (2012-II) & 59.97 \\
\hline HU & $67.8(2006)$ & 36.31 & $61.7(2014)$ & 28.97 \\
\hline IE & 67 (2007) & 58.64 & 70 (2011) & 52.44 \\
\hline IT & 80.5 (2008) & 65.05 & 75.2 (2013) & 57.22 \\
\hline LV & 61 (2006) & 53.7 & 59.5 (2011) & 30.24 \\
\hline LT & 48.6 (2008) & 20.98 & $52.9(2012)$ & 47.35 \\
\hline LU & 85.2 (2009) & 90.76 & 91.4 (2013) & 85.55 \\
\hline MT & 93.3 (2008) & 78.79 & 93 (2013) & 74.8 \\
\hline $\mathrm{NL}$ & 80.4 (2006) & 36.75 & 74.3 (2012) & 37.32 \\
\hline PL & 53.8 (2007) & 24.53 & 48.9 (2011) & 23.83 \\
\hline PT & 59.7 (2007) & 36.77 & $58.1(2011)$ & 33.67 \\
\hline RO & 39.2 (2008) & 27.67 & 41.8 (2012) & 32.44 \\
\hline SK & 54.7 (2006) & 19.64 & 59.1 (2012) & 13.05 \\
\hline SI & 63.1 (2008) & 28.37 & 64.7 (2011) & 24.55 \\
\hline ES & 73.9 (2008) & 44.87 & 71.7 (2011) & 43.81 \\
\hline SE & 82 (2006) & 45.53 & 84.6 (2010) & 51.07 \\
\hline UK & $61.3(2006)$ & 34.7 & $65.1(2010)$ & 35.4 \\
\hline
\end{tabular}

Note: There have been six national elections in 2014. Hungary had one in April 2014 and Belgium had simultaneous first-order and EP elections. However, Bulgaria (Oct.), Latvia (Oct.), Slovenia (July) and Sweden (Sept.) had them after May 2014 elections. For this reason, they are not included in this table.

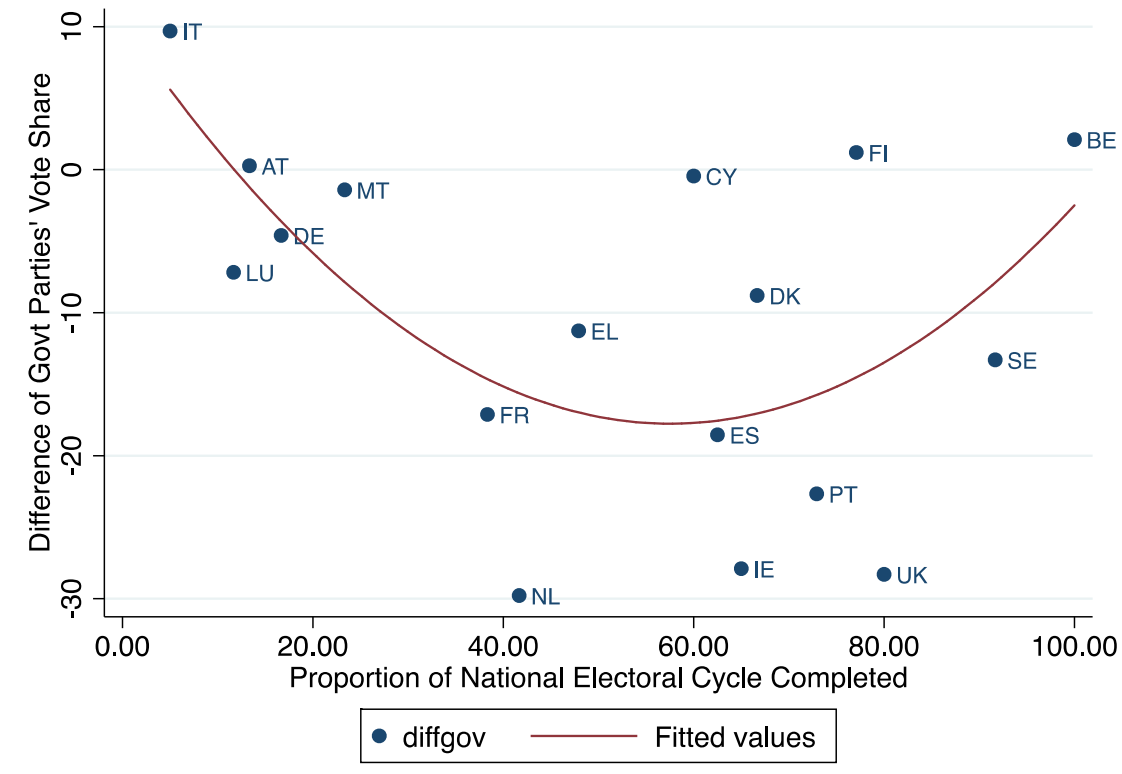

Figure A1. The electoral cycle and vote difference of the governing parties, for Western Europe. 


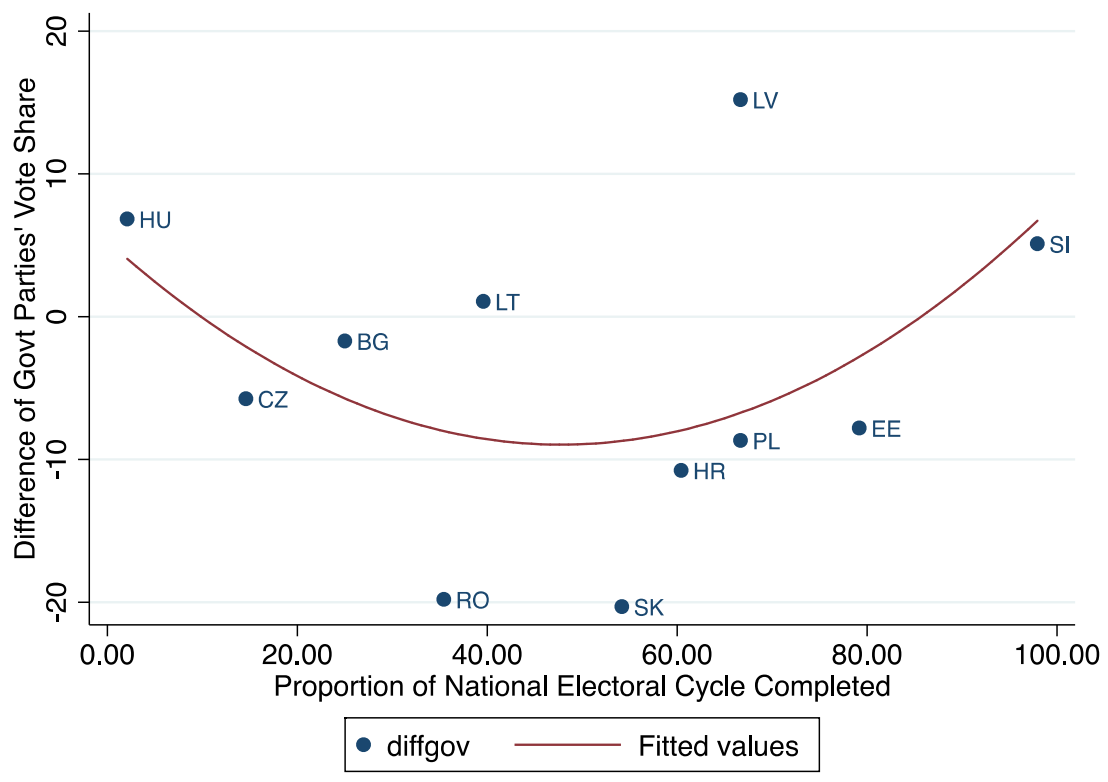

Figure A2. The electoral cycle and vote difference of the governing parties, for Eastern Europe. 